\title{
Rumen microbial and fermentation characteristics are affected differently by bacterial probiotic supplementation during induced lactic and subacute acidosis in sheep
}

Abderzak Lettat ${ }^{1,2,4}$, Pierre Nozière ${ }^{1}$, Mathieu Silberberg ${ }^{1}$, Diego P Morgavi ${ }^{1}$, Claudette Berger ${ }^{3}$ and Cécile Martin ${ }^{1 *}$

\begin{abstract}
Background: Ruminal disbiosis induced by feeding is the cause of ruminal acidosis, a digestive disorder prevalent in high-producing ruminants. Because probiotic microorganisms can modulate the gastrointestinal microbiota, propionibacteria- and lactobacilli-based probiotics were tested for their effectiveness in preventing different forms of acidosis.

Results: Lactic acidosis, butyric and propionic subacute ruminal acidosis (SARA) were induced by feed chalenges in three groups of four wethers intraruminally dosed with wheat, corn or beet pulp. In each group, wethers were either not supplemented (C) or supplemented with Propionibacterium P63 alone (P) or combined with L. plantarum $(L p+P)$ or $L$. rhamnosus $(L r+P)$. Compared with $C$, all the probiotics stimulated lactobacilli proliferation, which reached up to $25 \%$ of total bacteria during wheat-induced lactic acidosis. This induced a large increase in lactate concentration, which decreased ruminal pH. During the corn-induced butyric SARA, Lp + P decreased Prevotella spp. proportion with a concomitant decrease in microbial amylase activity and total volatile fatty acids concentration, and an increase in xylanase activity and $\mathrm{pH}$. Relative to the beet pulp-induced propionic SARA, P and Lr+P improved ruminal pH without affecting the microbial or fermentation characteristics. Regardless of acidosis type, denaturing gradient gel electrophoresis revealed that probiotic supplementations modified the bacterial community structure.
\end{abstract}

Conclusion: This work showed that the effectiveness of the bacterial probiotics tested depended on the acidosis type. Although these probiotics were ineffective in lactic acidosis because of a deeply disturbed rumen microbiota, some of the probiotics tested may be useful to minimize the occurrence of butyric and propionic SARA in sheep. However, their modes of action need to be further investigated.

Keywords: Acidosis, DGGE, Microbiota, Probiotics, qPCR, Rumen, SARA

\section{Background}

The rumen constitutes an effective animal-microbe mutualism system from which both partners derive benefit [1]. Current feeding practices in high-producing beef and dairy cattle use highly fermentable diets to increase growth rates and milk production, but because of microbial disturbances, they predispose cattle to digestive

\footnotetext{
* Correspondence: cecile.martin@clermont.inra.fr

'INRA, UR1213 Herbivores, Centre de Recherches de Clermont-Ferrand/Theix, F-63122 Saint Genès, Champanelle, France

Full list of author information is available at the end of the article
}

disorders such as ruminal acidosis [2]. Field studies in Europe and the USA estimate that 11 to $19 \%$ of early lactation and 18 to $26 \%$ of mid-lactation dairy cows have subacute ruminal acidosis (SARA) [3]. As it affects animal health and reduces performance, SARA is considered to be the most important nutritional disorder for ruminants $[4,5]$. Among the strategies developed to prevent SARA, the use of chemical buffers [6], ionophores [7] and probiotics based on yeast such as Saccharomyces cerevisiae $[8,9]$ have been found to stabilize ruminal $\mathrm{pH}$ and improve animal production. Contrastingly, there is

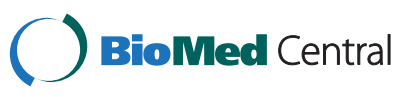


less information on the use of bacterial probiotics. Supplementation with lactate-producing bacteria or combining them with bacteria that utilize lactate was reported to decrease lactate and increase propionate in the rumen and thus could help to prevent SARA [10,11]. However, positive effects of bacterial probiotics on ruminal $\mathrm{pH}$ were observed only when these were associated with yeast $[11,12]$, and their effect on the ruminal microbiota has not yet received enough attention. Because several factors including animal models, diets, microbial strains and doses may affect probiotic effectiveness in preventing SARA, we hypothesized that the ruminal fermentation patterns could influence the effect of bacterial probiotics. In the present work, the effects of Lactobacillus and Propionibacterium supplementation on ruminal microbial and fermentation characteristics were investigated using a previously developed model of ruminal acidosis in wethers favoring lactic, propionic or butyric fermentation pathways [13].

\section{Methods}

\section{Ethics statement}

The experiment was conducted at the animal experimental facilities of the INRA Herbivores Research Unit (Saint-Genès Champanelle, France). Procedures on animals complied with the guidelines for animal research of the French Ministry of Agriculture and all other applicable national and European guidelines and regulations. The experiment was approved by the Auvergne regional ethics committee for animal experimentation, approval number CE1-10.

\section{Wethers, diets and treatments}

Twelve 3-year old rumen-cannulated Texel wethers were used to examine the effect of bacterial probiotic supplementation on rumen microbial and fermentation characteristics during induced lactic acidosis and SARA. The wethers weighed $60.7 \pm 3.3 \mathrm{~kg}$ (mean \pm SD) at the start of the experiment and were housed in individual stalls $(1.0 \times 1.50 \mathrm{~m})$ with feed-bunks and free access to water and mineralized salts blocks. The 12 wethers were allocated to three groups differing in the nature of the feed challenge (wheat, corn or beet pulp) used to induce acidosis. Within each group, the four wethers were randomly assigned to four treatments in a $4 \times 4$ Latin square design with 24-d periods. Treatments were: 1) control without probiotics (C), 2) Propionibacterium P63 (P), 3) Lactobacillus plantarum strain 115 plus $\mathbf{P}(\mathbf{L p}+\mathbf{P})$ and 4) Lactobacillus rhamnosus strain 32 plus $\mathbf{P}(\mathbf{L r}+\mathbf{P})$. Before their administration, the different treatments were prepared in gelatin capsules $(2 \mathrm{~g} / \mathrm{d})$, and then introduced in the rumen through the cannula just before the morning feeding or acidosis induction, at a dose of $1 \times 10^{11} \mathrm{CFU} /$ wether/d. The wethers on treatment $\mathrm{C}$ received only the carrier composed of lactose. The probiotics were specially prepared for this study by Danisco SAS (Dangé-Saint-Romain, France).

In the first $21 \mathrm{~d}$ of each period (adaptation period), the wethers were fed at $90 \%$ of their ad libitum intake in two equal portions $(0900 \mathrm{~h}$ and $1600 \mathrm{~h})$ with a basal non-acidogenic diet made of alfalfa hay and wheat-based concentrate (4:1 ratio on dry matter basis). This was followed by three consecutive days of acidosis induction (feed challenge period) where the wethers were intraruminally dosed with rapidly fermentable carbohydrates [13]. Briefly, the morning feeding was replaced by an intraruminal supply of ground concentrate $(3 \mathrm{~mm}$ screen) representing $1.2 \%$ of body weight (BW). Three types of concentrates differing in the nature and degradation rate of their carbohydrates were used: wheat (readily fermentable starch), corn (slowly fermentable starch) and beet pulp (easily digestible fibers) to induce lactic acidosis, butyric SARA and propionic SARA, respectively. At $1600 \mathrm{~h}$ the wethers received $520 \mathrm{~g}$ of hay to help them restore their ruminal buffering capacity. The chemical composition of the feeds used in the basal diet and feed challenges for acidosis induction is indicated in Table 1.

To minimize the carryover from period to period and help the rumen return more rapidly to an equilibrium state (especially in the case of lactic acidosis), the rumen of each wether was manually half-emptied on the last day of periods 1 to 3 , and replaced by a rumen content isolated from three additional wethers fed the same basal diet.

Rumen sample collection and treatments before analysis During the 3- $\mathrm{d}$ feed challenge period, ruminal content samples $(200 \mathrm{~g})$ were taken each day from the ruminal ventral sac $1 \mathrm{~h}$ before, and $3 \mathrm{~h}$ and $6 \mathrm{~h}$ after intraruminal feed dosing.

Ruminal $\mathrm{pH}$ was immediately measured with a portable $\mathrm{pH}$-meter (CG840, electrode $\mathrm{Ag} / \mathrm{AgCl}$, Schott

Table 1 Chemical composition of the feeds used in basal diet and in feed challenges for acidosis induction (g/100 g DM)

\begin{tabular}{lcccccc}
\hline & \multicolumn{2}{c}{ Basal diet $^{\mathbf{1}}$} & & \multicolumn{3}{c}{ Feed challenges $^{\mathbf{2}}$} \\
\cline { 2 - 6 } & Hay & Concentrate $^{\mathbf{3}}$ & & Wheat & Corn & Beet pulp \\
\hline NDF & 68.1 & 8.2 & 17.7 & 15.4 & 38.9 \\
\hline ADF & 40.7 & 4.9 & 4.3 & 3.3 & 19.9 \\
\hline Starch & $\mathrm{nd}^{4}$ & 65.6 & 62.0 & 72.4 & nd \\
\hline CP & 7.3 & 14.3 & 14.1 & 8.8 & 8.6
\end{tabular}

${ }^{1}$ Natural grassland hay:wheat-based concentrate (4:1 ratio on DM basis).

${ }^{2}$ Feed challenges: $1.2 \%$ body weight (BW) of ground wheat, corn or beet pulp was intraruminally dosed each morning of the feed challenge period. BW was $60.7 \pm 3.3 \mathrm{~kg}$ at the beginning of the experiment.

${ }^{3}$ Concentrate: wheat based concentrate with $3 \%$ molasses.

${ }^{4}$ nd: not detected. 
Geräte, Hofheim, Germany). The samples were then treated for measurement of microbial and fermentation characteristics as follows: on $\mathrm{d} 1$ and $\mathrm{d} 3$ at $-1 \mathrm{~h}$ and $3 \mathrm{~h}$ relative to intraruminal dosing, $30 \mathrm{~g}$ of ruminal content was immediately taken to the laboratory for enzyme extraction from the solid-adherent microorganisms (SAM) under anaerobic conditions. At the same time, $30 \mathrm{~g}$ of ruminal content was homogenized in ice using a Polytron grinding mill (Kinematica $\mathrm{GmbH}$, Steinhofhalde Switzerland) at speed 5, for two 1 min cycles with $1 \mathrm{~min}$ rest in ice between cycles. Two aliquots of $1.5 \mathrm{~g}$ were then stored at $-80^{\circ} \mathrm{C}$ until DNA extraction for bacterial qPCR and PCR-DGGE analysis. For each sampling time, an aliquot of ruminal contents was dried at $103^{\circ} \mathrm{C}$ for $24 \mathrm{~h}$ for dry matter (DM) determination. At all sampling times, $100 \mathrm{~g}$ of ruminal content was strained through a polyester monofilament fabric $(250 \mu \mathrm{m}$ mesh aperture) and the filtrate was used for analysis of volatile fatty acids (VFAs), lactate, $\mathrm{NH}_{3}-\mathrm{N}$ and for protozoa counting. For VFAs, $0.8 \mathrm{~mL}$ of ruminal filtrate was mixed with $0.5 \mathrm{~mL}$ of a $0.5 \mathrm{~N} \mathrm{HCl}$ solution containing $0.2 \%(\mathrm{w} / \mathrm{v})$ metaphosphoric acid and $0.4 \%(\mathrm{w} / \mathrm{v})$ crotonic acid. For $\mathrm{NH}_{3}-\mathrm{N}, 5 \mathrm{~mL}$ of ruminal filtrate was mixed with $0.5 \mathrm{~mL}$ of $5 \% \mathrm{H}_{3} \mathrm{PO}_{4}$. These samples were stored at $-20^{\circ} \mathrm{C}$ until analysis. For protozoa, $3 \mathrm{~mL}$ of the fresh filtrate was mixed with $3 \mathrm{~mL}$ of methyl green, formalin and saline solution (MFS) and preserved from light until counting.

\section{Measurements}

\section{Bacterial quantification by quantitative $P C R$}

Genomic DNA was extracted using the FastDNA ${ }^{\circledR}$ Spin Kit, and purified with the GeneClean ${ }^{\circledR}$ Turbo Kit (MP Biomedicals, Illkirch, France) according to the manufacturer's instructions with minor modifications. Briefly, $250 \mathrm{mg}$ of frozen milled ruminal contents was weighed into the tube provided containing silica beads and lysis buffer. Bacteria were lyzed using a beadbeater (Precellys 24, Bertin Technology, France). The yield and purity of the extracted DNA were assessed by optical density measurement with a Nanoquant Infinite M200 spectrophotometer (Tecan Austria GmbH, Grödig, Austria), using a dedicated quantification plate. Absorbance intensity at $260 \mathrm{~nm}$ was used to assay nucleic acids in $2 \mu \mathrm{L}$ of sample. Absorbance ratios $260 / 280$ and 260/230 were used to check sample purity.

The quantitative PCR (qPCR) was carried out using the StepOnePlus ${ }^{\mathrm{TM}}$ real-time PCR system and software (Applied Biosystems, Courtaboeuf, France). Detection was based on SYBR green chemistry. Total bacteria and selected species were quantified by targeting the rrs gene (Table 2). The reaction mix contained $0.75 \times$ SYBR Premix Ex Taq (Lonza Verviers SPRL, Verviers, Belgium), $0.5 \mu \mathrm{M}$ of each forward and reverse primer and $80 \mathrm{ng}$ of DNA template. Each reaction was run in triplicate in a final volume of $20 \mu \mathrm{L}$ in 96-well reaction plates (Applied Biosystems, Courtaboeuf, France). Amplification programs consisted of one cycle at $95^{\circ} \mathrm{C}(10 \mathrm{~s})$ and $40 \mathrm{de}-$ naturing cycles at $95^{\circ} \mathrm{C}(15 \mathrm{~s})$ and annealing at $60^{\circ} \mathrm{C}$ (30 s) for total bacteria, Prevotella genus, Ruminococcus albus, Fibrobacter succinogenes and Ruminococcus flavefaciens. For Streptococcus bovis the annealing temperature was $63.9^{\circ} \mathrm{C}(30 \mathrm{~s})$, while the amplification of Lactobacillus consisted of one cycle at $95^{\circ} \mathrm{C}(10 \mathrm{~min})$ and $40 \mathrm{de}-$ naturing cycles at $95^{\circ} \mathrm{C}(30 \mathrm{~s})$ and annealing at $60^{\circ} \mathrm{C}$ (1 min). Absolute quantification was carried out for all bacteria using specific $16 \mathrm{~S}$ rDNA standards from

Table 2 rrs gene based primers used for qPCR quantification and PCR-DGGE

\begin{tabular}{|c|c|c|c|c|}
\hline Target organism & Primer set & Primer sequences $5^{\prime}$ - 3' & Assay & Reference \\
\hline \multirow[t]{2}{*}{ Total bacteria } & $520 \mathrm{~F}$ & AGCAGCCGCGGTAAT & $\mathrm{qPCR}$ & [14] \\
\hline & 799 R2 & CAGGGTATCTAATCCTGTT & & \\
\hline Fibrobacter & FibSuc3F & GCGGGTAGCAAACAGGAT TAGA & $\mathrm{qPCR}$ & {$[15]$} \\
\hline succinogenes & FibSuc3R & CCCCCGGACACCCAGTAT & & \\
\hline Ruminococcus & RumAlb3F & TGTTAACAGAGGGAAGCAAAGCA & $\mathrm{qPCR}$ & [15] \\
\hline albus & RumAlb3R & TGCAGCCTACAATCCGAACTAA & & \\
\hline Ruminococcus & RumFla3F & TGGCGGACGGGTGAGTAA & $\mathrm{qPCR}$ & {$[15]$} \\
\hline flavefaciens & RumFla3R & TTACCATCCGTTTCCAGAAGC T & & \\
\hline Genus & PrevGen4F & GGTTCTGAGAGGAAGGTCCCC & $\mathrm{qPCR}$ & {$[15]$} \\
\hline Prevotella & PrevGen4R & TCCTGCACGCTACTTGGCTG & & \\
\hline Streptococcus & StrBov2F & TTCCTAGAGATAGGAAGTTTCTTC GG & $\mathrm{qPCR}$ & [15] \\
\hline bovis & StrBov2R & ATG ATG GCA ACT AAC AAT AGG GGT & & \\
\hline Genus & Lacto $05 \mathrm{~F}$ & AGC AGT AGG GAA TCT TCC A & $\mathrm{qPCR}$ & {$[16]$} \\
\hline Lactobacillus & Lacto 04R & CGCCACTGGTGTTCYTCCATATA & & \\
\hline \multirow[t]{2}{*}{ Total bacteria } & GC +Eub340F & CGCCCGCCGCGCGCGGCGGGCGGGGCG GGGGCACGGGGGGTCCTACGGGAGGCAGCAG & DGGE & [17-19] \\
\hline & HDA2R & GTA TTA CCG CGG CTG CTG GCA C & & \\
\hline
\end{tabular}


R. flavefaciens c94 (ATCC 19208), R. albus 7(ATCC 27210), F. succinogenes S85 (ATCC 19169), S. bovis (DSM 20480), P. bryantii B14 (DSM 11371), and Lb. acidophilus. The results for counting of each species are expressed as \% of total bacteria/g DM of rumen content. Only assays that fell in the range $90-110 \%$ of efficiency and with $r^{2} \geq 0.98$ were considered for further analysis.

\section{PCR and Denaturing Gradient Gel Electrophoresis (DGGE)}

The V3 region of the bacterial rrs gene was amplified in PCR using primers Eub340F [17,18] and HDA2R [19]. The Eub340F primer was modified for broader bacterial coverage and was tested in association with HDA2R on pure culture microorganisms. In all cases, the primer pair produced single PCR products that matched the target sequence from known microorganisms (E. Galbraith, unpublished data). For DGGE, a 40 bp GC clamp was added to the 5' end of the forward primer Eub340F (Table 2). In $50 \mu \mathrm{L}$ final volume, each reaction contained 2.5 units $/ \mu \mathrm{L}$ of Platinum Taq DNA Polymerase (Invitrogen, Carlsbad, CA), $1 \times$ PCR Buffer, $200 \mu \mathrm{M}$ dNTP mix, $80 \mathrm{ng}$ of template DNA, and $0.5 \mu \mathrm{M}$ of each primer. PCR was performed using the GeneAmp PCR System 2700 thermocycler (Applied Biosystems, Foster City, CA). We used the PCR program described by Smith and Mackie [20] with the following modification: 20 touchdown cycles were used instead of 10 , and the annealing temperature was decreased by $0.5^{\circ} \mathrm{C}$ every cycle (instead of $1^{\circ} \mathrm{C}$ ) from 65 to $55^{\circ} \mathrm{C}$. PCR amplification products were analyzed on a 1\% E-gel 96 agarose (Invitrogen, Carlsbad, CA). Amplicon size and concentration were estimated using E-gel Low Range Quantitative DNA Ladder (Invitrogen, Carlsbad, CA) and Syngene Bioimaging System and GeneSnap software (Syngene, Frederick, MD).

The DGGE gels were cast using the DCode universal mutation detection system (BioRad, Hercules, CA) as previously described [19]. Briefly, polyacrylamide gels (8\%) were prepared and run using $0.5 \times$ TAE buffer. A gradient maker was used (CBS Scientific Co., Del Mar, CA) to prepare gels that contained a $30-60 \%$ gradient of urea and formamide increasing in the direction of electrophoresis. A $100 \%$ denaturing solution contained $40 \%$ (vol/vol) formamide and 7.0 M urea. The polyacrylamide gel wells were loaded with $10 \mu \mathrm{L}$ of PCR product and $10 \mu \mathrm{L}$ of $2 \times$ loading dye $(0.05 \%$ bromophenol blue, $0.05 \%$ xylene cyanol and $70 \%$ glycerol). Within each feed challenge group, the DNA samples were pooled by treatment after the PCR amplification, and then loaded on the gel to assess the global community structure. The electrophoresis was conducted with a constant voltage of $130 \mathrm{~V}$ at $55^{\circ} \mathrm{C}$ for about $4 \mathrm{~h}$. Gels were stained with ethidium bromide solution $(0.5 \mu \mathrm{g} / \mathrm{mL}, 10 \mathrm{~min})$, and washed $(0.5 \times$ TAE buffer, $10 \mathrm{~min})$. Gel images were acquired using Syngene Bioimaging System and GeneSnap software (Syngene, Frederick, MD). The GelCompar II v5.10 software (Applied Maths, Belgium) was used to analyze the DGGE gels. To normalize the differences among gels, the same standard was used for each gel. The percentage of similarity between gel standards was $96 \%$.

The DGGE profiles were normalized and compared using hierarchical clustering to join similar profiles in groups [21]. To this end, all the images of DGGE gels were matched using the standard and the bands were quantified after a local background subtraction. A $1 \%$ tolerance in the band position was applied. The cluster analysis was based on Dice's correlation index and the clustering was done with the unweighted pair-group method using arithmetic averages (UPGMA).

\section{Protozoa counting}

Protozoa were enumerated in a Dolfuss cell (Elvetec Services, Clermont-Ferrand, France), using a photonic microscope according to the method of Jouany and Senaud [22].

\section{Polysaccharidase activities of solid-associated microorganisms}

Polysaccharidase activities involved in the degradation of plant cell wall (EC 3.2.1.4 - cellulase and EC 3.2.1.8 endo-1,4- $\beta$-xylanase) and starch (EC 3.2.1.1 - $\alpha$-amylase) were determined from the solid-adherent microorganisms (SAM) as already described [23]. Briefly, $30 \mathrm{~g}$ of solid phase was washed with $350 \mathrm{~mL}$ anaerobic MES buffer $\left(2-\left(N\right.\right.$-morpholino) ethane sulfonic acid; $\left.\mathrm{pH} 6.5,39^{\circ} \mathrm{C}\right)$ to remove the non-associated and loosely-associated microbes, and then recovered by filtration $(100 \mu \mathrm{m})$. A $5 \mathrm{~g}$ sample of washed digesta containing the SAM was cut in an anaerobic environment, suspended in $25 \mathrm{~mL}$ of anaerobic MES buffer and stored at $-80^{\circ} \mathrm{C}$ pending enzyme extraction. The SAM fraction was broken up by defrosting and ultrasonic disintegration (four $30 \mathrm{~s}$ periods with $30 \mathrm{~s}$ intervals at $4^{\circ} \mathrm{C}$; Branson $250 \mathrm{D} 200 \mathrm{~W}$, Elvetec services, Clermont-Ferrand, France). Samples were centrifuged $\left(15,000 \mathrm{~g}, 15 \mathrm{~min}, 4^{\circ} \mathrm{C}\right)$ and the supernatant containing the released enzymes was stored in capped tubes at $-80^{\circ} \mathrm{C}$ before assay. Polysaccharidase activities were determined by assaying the amount of reducing sugars released from purified substrates (Birchwood-xylan, Sigma X-0502; carboxymethylcellulose, Sigma C-5678; potato starch, Sigma S-2004) after incubation for $1 \mathrm{~h}$ at $39^{\circ} \mathrm{C}$. Briefly, the reducing sugars were converted into colored products using PAHBAH (4hydroxybenzhydrazide) in the presence of bismuth and quantified spectrophotometrically at $410 \mathrm{~nm}$ [24]. The protein content of the enzyme preparations was determined according to Pierce and Suelter [25] using bovine serum albumin as standard in 96-well plates using the 
Nanoquant Infinite M200 spectrophotometer (Tecan Austria GmbH, Grödig, Austria). Enzyme activities were expressed in $\mu \mathrm{mol}$ of reducing sugar released per $\mathrm{g}$ of DM per hour (total activity) and in $\mu \mathrm{mol}$ of reducing sugar released per mg protein per hour (specific activity).

\section{Fermentation parameters}

Volatile fatty acids and lactate concentrations were determined by gas chromatography (CP 9002 Gas Chromatograph, Chrompack, Middelburg, Germany) and an enzymatic method (Enzyplus EZA 891+, D/L-Lactic Acid, Raisio Diagnostics, Rome, Italy) respectively as described in Lettat et al. [13]. For $\mathrm{NH}_{3}-\mathrm{N}$, thawed samples were centrifuged at $10,000 \mathrm{~g}$ for $10 \mathrm{~min}$ and $\mathrm{NH}_{3}-\mathrm{N}$ concentration was determined in the supernatant using the Berthelot reaction [26]. The reaction was carried out in duplicate in 96-well plates and read using the Nanoquant Infinite M200 spectrophotometer (Tecan Austria GmbH, Grödig, Austria).

\section{Statistical procedure}

All the data were analyzed in repeated time using the MIXED procedure of SAS, with $\mathrm{SP}(\mathrm{POW})$ as covariance structure for unequally spaced data. Within each Latin square, the period (1 to 4$)$, treatment (C vs. P, vs. Lp + P, vs. $\mathrm{Lr}+\mathrm{P})$, feed challenge day $(\mathrm{d} 1$ vs. $\mathrm{d} 3)$ and time $(-1 v s .+$ $6 \mathrm{~h}$ and -1 vs. $+3 \mathrm{~h}$ for rumen fermentation and microbiological parameters, respectively) were considered as fixed effects, and animal as random. Results were considered significant for $P \leq 0.05$. When treatment was significant, means were separated using orthogonal contrasts: $C$ vs. $(\mathrm{P}, \mathrm{Lp}+\mathrm{P}, \mathrm{Lr}+\mathrm{P}) ; \mathrm{P}$ vs. $(\mathrm{Lp}+\mathrm{P}, \mathrm{Lr}+\mathrm{P})$ and $\mathrm{Lp}+\mathrm{P}$ vs. $\mathrm{Lr}+\mathrm{P}$.

\section{Results and discussion}

Lactic acidosis is characterized by a mean ruminal $\mathrm{pH}$ $<5.2$ associated with high lactate concentration [27], whereas for SARA, where the condition is subtler, several definitions have been proposed [13,28,29]. For the purpose of this study, we used a mean value of 6.25 as the ruminal $\mathrm{pH}$ benchmark for SARA determination [30]. Based on the ruminal $\mathrm{pH}$ and fermentation patterns observed in this study during the 3-d feed challenge periods, acidosis induction was attained on $\mathrm{d} 3$ (data not shown). Lactic acidosis was induced with wheat, whereas butyric and propionic SARA were induced with corn and beet pulp, respectively. These results are similar to those of our previous study [13] in which these three acidosis forms were induced in wethers using the same feeds.

Irrespective of the acidosis, we also observed that the differences among treatments were accentuated during the three days of feed challenges, being maximal and significant only on the third day. Consequently, only data related to the effect of probiotic supplementations on the rumen characteristics on $\mathrm{d} 3$ are reported and discussed here.

\section{Lactic acidosis induced by wheat}

Lactic acidosis is a rare accidental pathology in which the ruminal ecosystem is completely disturbed. In this experiment, the mean and minimum ruminal $\mathrm{pH}$ were 5.25 and 4.86 respectively, concentration of lactate reaching $\sim 34 \mathrm{mM}$ and that of total VFAs $94 \mathrm{mM}$ for control wethers (Table 3 ). These values are classically observed in lactic acidosis situations [13,31]. Compared with the control animals, a drastic decrease in total bacteria was observed for $\mathrm{Lr}+\mathrm{P}$ fed wethers $(P<0.05$; Figure 1), whereas feeding $\mathrm{P}$ and $\mathrm{Lr}+\mathrm{P}$ decreased the population of protozoa $(P<0.05)$. Without significantly affecting fibrolytic activities (cellulase and xylanase), the three probiotic treatments reduced the proportion of the cellulolytic bacterium $F$. succinogenes, $\mathrm{Lr}+\mathrm{P}$ decreased $R$. albus while $R$. flavefaciens was not affected. The growth of lactate-producing bacteria (Lactobacillus spp. and $S$. bovis) was enhanced by probiotic supplementation. S. bovis proportion was highest for P-fed wethers whereas Lactobacillus spp. became a predominant bacterial group: from $1.7 \%$ in $\mathrm{C}$ up to $25 \%$ of total bacteria in probiotic-supplemented wethers $(P<0.05)$. Specific amylase activity was not significantly affected by probiotic supplementation, but the total activity was increased in $\mathrm{P}$-fed wethers $(P<0.05$; data not shown). As expected, lactobacilli proliferation caused an increase in lactate concentration that reached more than $60 \mathrm{mM}$ in probiotic-fed wethers $(P<0.05$; Table 3$)$, whereas total VFA concentrations were less than $35 \mathrm{mM}$ for $\mathrm{P}$ and $\operatorname{Lr}+\mathrm{P}(P<0.05)$, suggesting a decrease in microbial fermentative activity and a shift towards lactate production at the expense of VFAs $(P<0.05)$. It could be argued that the increase was due to the addition of exogenous lactobacilli. However, wethers that received only Propionibacterium P63 exhibited similar proportions of Lactobacillus spp. to those supplemented with a combination of Propionibacterium and Lactobacillus $(P=0.5)$. Therefore, it seems that the lactobacilli quantified were indeed autochthonous symbionts and that Propionibacterium P63 may improve the growth of this bacterial group. Lactate accumulation in the rumen can be explained by the increase in lactate producers as discussed above, but it might also be coupled to a decreased number or activity of lactate-utilizers. The bacterium $M$. elsdenii, which is considered to be the most efficient lactate-utilizer [10,32], was not detected in our samples (data not shown). As a result, lactate accumulation induced a drop in mean and minimum ruminal $\mathrm{pH}$, compared with $\mathrm{C}$ wethers $(-0.70$ and $-0.33 \mathrm{pH}$ units on average; $P<0.05)$. Among probiotic treatments, $\mathrm{pH}$ was 
Table 3 Effects of bacterial probiotic supplementation on rumen fermentation characteristics during acidosis induced by feed challenges

\begin{tabular}{|c|c|c|c|c|c|c|c|c|}
\hline & \multicolumn{4}{|c|}{ Treatments $^{1}$} & \multirow[b]{2}{*}{ SEM } & \multicolumn{3}{|c|}{$P$ value (Prob vs. C) ${ }^{2}$} \\
\hline & $C(n=4)$ & $P(n=4)$ & $L p+P(n=4)$ & $L r+P(n=4)$ & & $P$ & $L p+P$ & $L r+P$ \\
\hline \multicolumn{9}{|c|}{ Wheat-induced lactic acidosis } \\
\hline \multicolumn{9}{|l|}{ Ruminal pH } \\
\hline Mean & 5.25 & 4.55 & 4.76 & 4.33 & 0.15 & 0.001 & 0.02 & 0.0001 \\
\hline Minimum & 4.87 & 4.28 & 4.45 & 4.17 & 0.19 & 0.03 & 0.12 & 0.01 \\
\hline Total VFAs, mM & 93.6 & 33.9 & 76.7 & 33.5 & 14.4 & 0.01 & 0.32 & 0.001 \\
\hline Acetate $^{3}, \mathrm{~mol} \%$ & 72.6 & 87.0 & 78.1 & 92.5 & 4.10 & 0.01 & 0.34 & 0.001 \\
\hline Propionate, mol \% & 12.2 & 6.63 & 10.6 & 3.82 & 2.49 & 0.10 & 0.63 & 0.02 \\
\hline Butyrate, mol \% & 12.8 & 5.79 & 10.2 & 3.52 & 1.94 & 0.01 & 0.33 & 0.001 \\
\hline Minor VFAs ${ }^{4}, \mathrm{~mol} \%$ & 2.33 & 0.56 & 1.11 & 0.14 & 0.40 & 0.001 & 0.02 & 0.0001 \\
\hline Lactate, mM & 33.8 & 71.1 & 64.9 & 79.6 & 9.28 & 0.005 & 0.02 & 0.001 \\
\hline $\mathrm{NH}_{3}-\mathrm{N}, \mathrm{mM}$ & 6.53 & 3.58 & 4.25 & 2.44 & 1.16 & 0.03 & 0.09 & 0.003 \\
\hline Ethanol, mM & 6.57 & 12.4 & 17.2 & 14.4 & 1.85 & 0.02 & 0.0001 & 0.003 \\
\hline \multicolumn{9}{|c|}{ Corn-induced butyric subacute acidosis } \\
\hline \multicolumn{9}{|l|}{ Ruminal pH } \\
\hline Mean & 5.49 & 5.61 & 5.74 & 5.65 & 0.08 & 0.30 & 0.03 & 0.18 \\
\hline Minimum & 5.17 & 5.28 & 5.63 & 5.46 & 0.12 & 0.50 & 0.01 & 0.09 \\
\hline Total VFAs, mM & 107 & 85.7 & 81.6 & 94.4 & 7.79 & 0.03 & 0.01 & 0.19 \\
\hline Acetate, mol \% & 63.2 & 67.4 & 68.7 & 66.9 & 1.75 & 0.08 & 0.03 & 0.13 \\
\hline Propionate, mol \% & 17.0 & 14.2 & 14.5 & 15.5 & 1.09 & 0.07 & 0.19 & 0.31 \\
\hline Butyrate, mol \% & 16.9 & 14.7 & 12.1 & 13.5 & 1.41 & 0.26 & 0.02 & 0.09 \\
\hline Minor VFAs, mol \% & 2.88 & 3.68 & 4.29 & 4.09 & 0.44 & 0.20 & 0.02 & 0.05 \\
\hline Lactate, mM & 3.40 & 3.78 & 3.22 & 3.49 & 0.86 & 0.71 & 0.87 & 0.92 \\
\hline $\mathrm{NH}_{3}-\mathrm{N}, \mathrm{mM}$ & 0.74 & 0.73 & 0.71 & 1.15 & 0.98 & 0.99 & 0.98 & 0.76 \\
\hline Ethanol, mM & 3.15 & 3.60 & 2.72 & 2.74 & 0.36 & 0.38 & 0.40 & 0.42 \\
\hline \multicolumn{9}{|c|}{ Beet pulp-induced propionic subacute acidosis } \\
\hline \multicolumn{9}{|l|}{ Ruminal pH } \\
\hline Mean & 5.67 & 5.94 & 5.87 & 5.93 & 0.08 & 0.02 & 0.08 & 0.02 \\
\hline Minimum & 5.55 & 5.84 & 5.72 & 5.83 & 0.11 & 0.05 & 0.27 & 0.06 \\
\hline Total VFAs, mM & 114 & 112 & 104 & 100 & 6.66 & 0.89 & 0.33 & 0.16 \\
\hline Acetate, mol \% & 67.4 & 68.6 & 68.4 & 67.8 & 1.15 & 0.46 & 0.55 & 0.79 \\
\hline Propionate, mol \% & 22.5 & 21.5 & 21.9 & 22.3 & 0.83 & 0.38 & 0.61 & 0.88 \\
\hline Butyrate, mol \% & 8.52 & 8.40 & 8.18 & 8.34 & 0.49 & 0.86 & 0.85 & 0.77 \\
\hline Minor VFAs, mol \% & 1.50 & 1.48 & 1.52 & 1.46 & 0.26 & 0.94 & 0.96 & 0.91 \\
\hline Lactate, mM & 2.71 & 2.01 & 1.52 & 2.01 & 1.46 & 0.73 & 0.56 & 0.73 \\
\hline $\mathrm{NH}_{3}-\mathrm{N}, \mathrm{mM}$ & 0.55 & 0.51 & 0.57 & 0.57 & 0.74 & 0.97 & 0.99 & 0.98 \\
\hline Ethanol, mM & 3.34 & 3.22 & 2.64 & 2.84 & 0.48 & 0.86 & 0.31 & 0.47 \\
\hline
\end{tabular}

${ }^{1}$ Treatment with $\mathrm{C}=$ control without probiotic; $\mathrm{P}=$ Propionibacterium $\mathrm{P} 63 ; \mathrm{Lp}+\mathrm{P}=$ L. plantarum $+\mathrm{P} 63 ; \mathrm{Lr}+\mathrm{P}=\mathrm{L}$. rhamnosus $+\mathrm{P} 63 .{ }^{2}$ Effect of each probiotic treatment vs. control wether (C). ${ }^{3}$ Individual VFAs are expressed in $\%$ of total VFAs. ${ }^{4}$ Minor VFAs: sum of iso-butyrate, iso-valerate, valerate and caproate. The fermentation characteristics were determined on $\mathrm{d} 3 \mathrm{at} 6 \mathrm{~h}$ after feed challenges induced acidosis.

lowest for $\mathrm{Lr}+\mathrm{P}$, intermediate for $\mathrm{P}$ and highest for $\mathrm{LP}+$ $\mathrm{P}(P<0.05)$. $\mathrm{P}$ and $\mathrm{Lr}+\mathrm{P}$ decreased propionate and butyrate proportions, whereas minor VFAs were reduced by all three probiotics $(P<0.05)$. The concentration of $\mathrm{NH}_{3}-\mathrm{N}$ was reduced for $\mathrm{P}$ and $\mathrm{Lr}+\mathrm{P}$ fed wethers $(P<0.05)$, whereas it was numerically lower for those fed
$\mathrm{Lp}+\mathrm{P}$. This decrease in $\mathrm{NH}_{3}-\mathrm{N}$ may be due to a decrease in deamination activity, as the proportion of Prevotella spp., a dominant bacterial genus that plays a central role in amino acid deamination in the rumen [33], was numerically lower in wethers fed with $\mathrm{Lp}+\mathrm{P}$ and $\mathrm{Lr}+\mathrm{P}$ $(P=0.1$ and 0.06 ; respectively). In addition, probiotic 

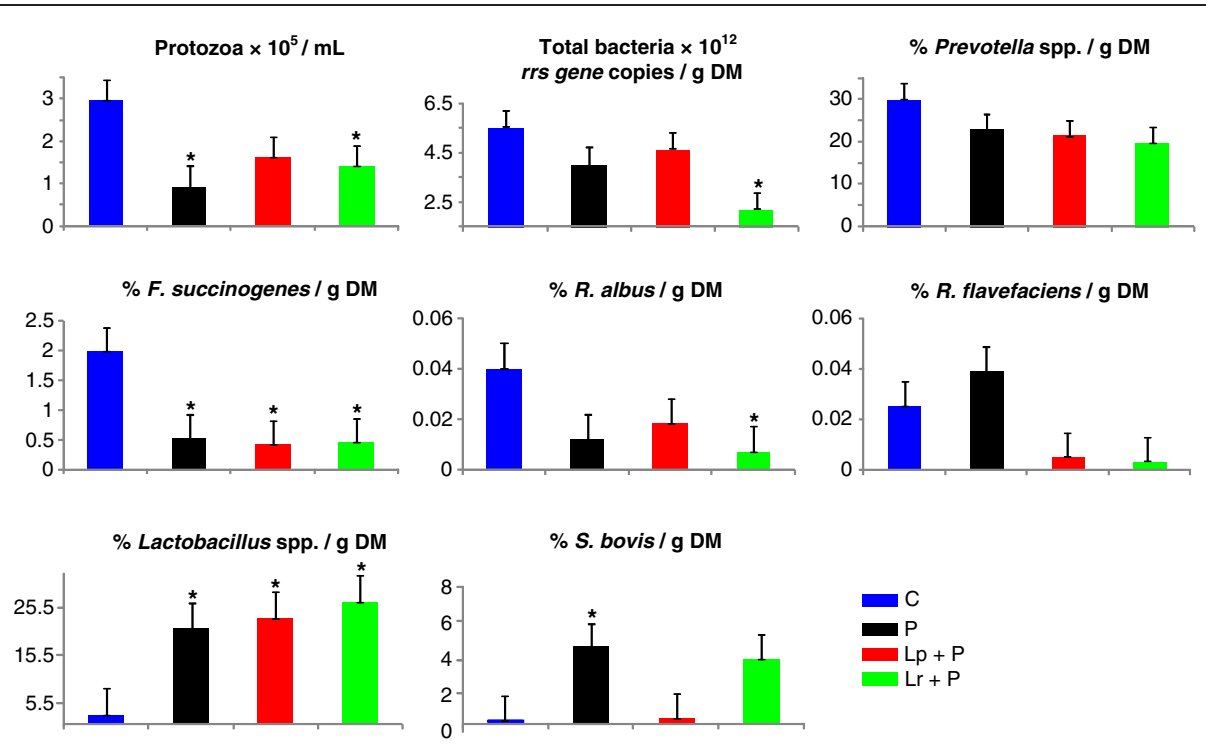

S. bovis / g DM
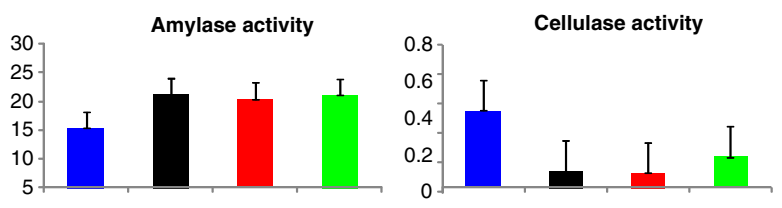

Figure 1 Effects of bacterial probiotic supplementation on the rumen microbial parameters during wheat-induced lactic acidosis. Acidosis was induced during 3 consecutive days. Protozoa, bacteria and polysaccharidase activities were quantified $3 \mathrm{~h}$ after acidosis induction on day 3. Bacterial species are expressed as \% of total bacteria per gram of dry matter (DM). Polysaccharidase activities are expressed as $\mu$ mol of reducing sugar $/ \mathrm{mg}$ protein/h. The treatments were identified as $C=$ control without probiotic; $P=$ Propionibacterium $P 63 ; L P+P=$

L. plantarum $+P 63 ; L r+P=L$. rhamnosus $+P 63$. Each single point is a mean of 4 data points from the 4-periods Latin square. Error bars represent standard error of the means. Probiotic treatments that significantly differ from control are indicated by * for $P \leq 0.05$.

supplementation increased ethanol concentration, a minor fermentation product that does not accumulate in the rumen except during lactic acidosis [34,35] because of the heterofermentative metabolism of glucose by lactobacilli, which leads to lactate and ethanol production [36].

According to the fermentation and microbial characteristics, the negative effects induced by probiotic supplementation were more marked for $\mathrm{P}$ and $\mathrm{Lr}+\mathrm{P}$ than for $\mathrm{Lp}+\mathrm{P}$. A possible explanation for this difference could be that the proportion of $S$. bovis was higher in wethers treated with $\mathrm{P}(P<0.05)$ and almost reached significance for $\mathrm{Lr}+\mathrm{P}$-fed wethers $(P=0.06)$ as compared with those supplemented with $\mathrm{Lp}+\mathrm{P}(P=0.9)$. Thus $S$. bovis could be considered as a worsening factor rather than an initial cause of the chain of events resulting in lactic acidosis in ruminants [37-39]. Also, in contrast to $\mathrm{P}$ and $\mathrm{Lr}+\mathrm{P}$ feeding, the supplementation with $\mathrm{Lp}+\mathrm{P}$ did not reduce the protozoa population $(P=0.16)$. Thus maintaining a higher protozoal population, which is known to stabilize rumen $\mathrm{pH}$, may explain why $\mathrm{Lp}+\mathrm{P}$ was the "least bad" of the three probiotic treatments tested $[4,40]$.
The DGGE analysis of the ruminal bacterial population showed that regardless of the feed used, most of the $\mathrm{d} 1$ and $\mathrm{d} 3$ samples clustered in two different groups, with 73.7 and $65.3 \%$ similarity, respectively (Figure 2). Separation into distinct groups indicates that the bacterial structure was modified by acidosis induction. On d3, DGGE profiles from wethers challenged with wheat clustered together $(87.5 \%$ similarity). The number of bands, interpreted as an index of richness, was greater on $\mathrm{d} 3$ than on d1, with an average of 35 vs. 22 bands, respectively. This result is somewhat surprising because lactic acidosis is thought to induce a less rich bacterial community owing to the large increase in lactobacilli and decrease in other bacteria as revealed by qPCR [41]. The higher richness could be due to an increased diversity of lactate-producing bacteria. In future studies, the diversity of lactobacilli and streptococci species and strains should be assessed by the use of second generation sequencing methods or specific techniques such as ribotyping. Unfortunately, explanations are still lacking due to the absence of similar studies in the literature. In addition, a band only present at $\mathrm{d} 3$ for wethers supplemented with $\mathrm{P}$ has been detected. Further identification 


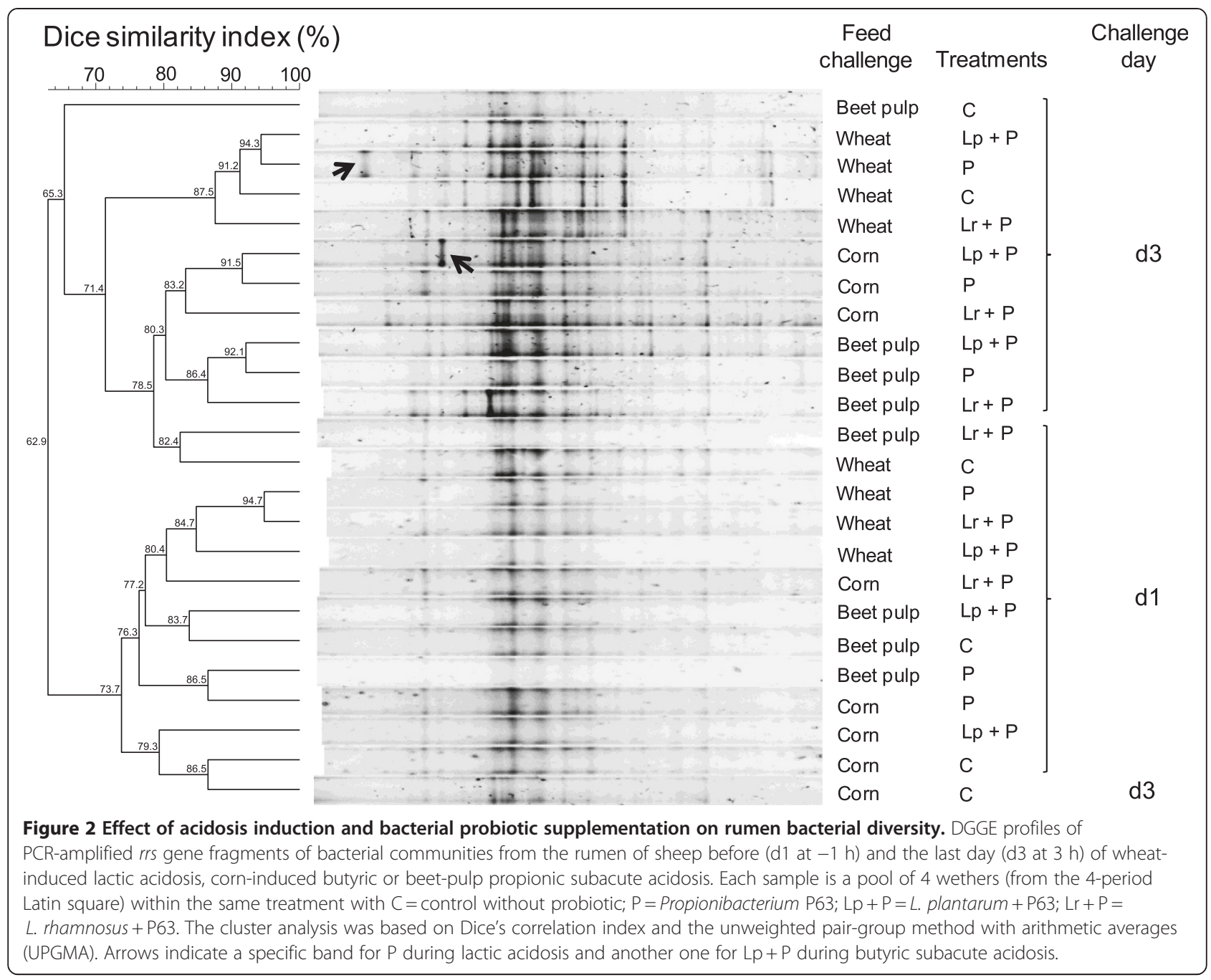

of this specific band together with other bands that appeared or disappeared following lactic acidosis induction will enhance our knowledge on how the bacterial communities are affected by acidosis onset and probiotic supplementation.

In these experimental conditions, the probiotics used were not effective in alleviating the onset of rumen lactic acidosis in challenged wethers. Instead, supplementation with probiotics had a worsening, catalytic effect on lactic acidosis by enhancing lactate-producing bacteria proliferation and altering fermentation parameters (decrease in $\mathrm{pH}$ and VFAs, increase in lactate concentration), important for the development of this digestive disorder $[4,42]$. In conclusion, bacterial probiotics such as those of the type tested in this work cannot be used to prevent lactic acidosis onset in ruminants. Good dietary management practices are still the best way to avoid this rare accidental digestive disorder.
Butyric and propionic SARA induced by corn and beet pulp In $C$ wethers, butyric acidosis induced by corn challenge was characterized by a mean ruminal $\mathrm{pH}$ of 5.49 , total VFA concentration of $\sim 107 \mathrm{mM}$ with $\sim 17 \%$ of butyrate and a weak concentration of lactate (3.4 mM; Table 3), in agreement with previous reports of butyric SARA $[13,40,43]$. Regarding the microbial composition and activities (Figure 3), total and cellulolytic bacteria and protozoa were not affected by probiotic supplementation. Feeding $\mathrm{Lp}+\mathrm{P}$ and $\mathrm{Lr}+\mathrm{P}$ resulted in lower $S$. bovis and Prevotella spp. proportion $(P<0.05)$, while the decrease in Lactobacillus spp. proportion almost reached significance in $P$-fed wethers $(P=0.06)$. The treatment $\mathrm{Lp}+\mathrm{P}$ reduced both total (data not shown) and specific amylase activities and increased specific xylanase activity $(P<0.05)$, whereas specific amylase activity was numerically lower in wethers fed with $\mathrm{Lr}+\mathrm{P}$. These moderate microbiological shifts were accompanied by some changes in the fermentation patterns. Wethers supplemented with 

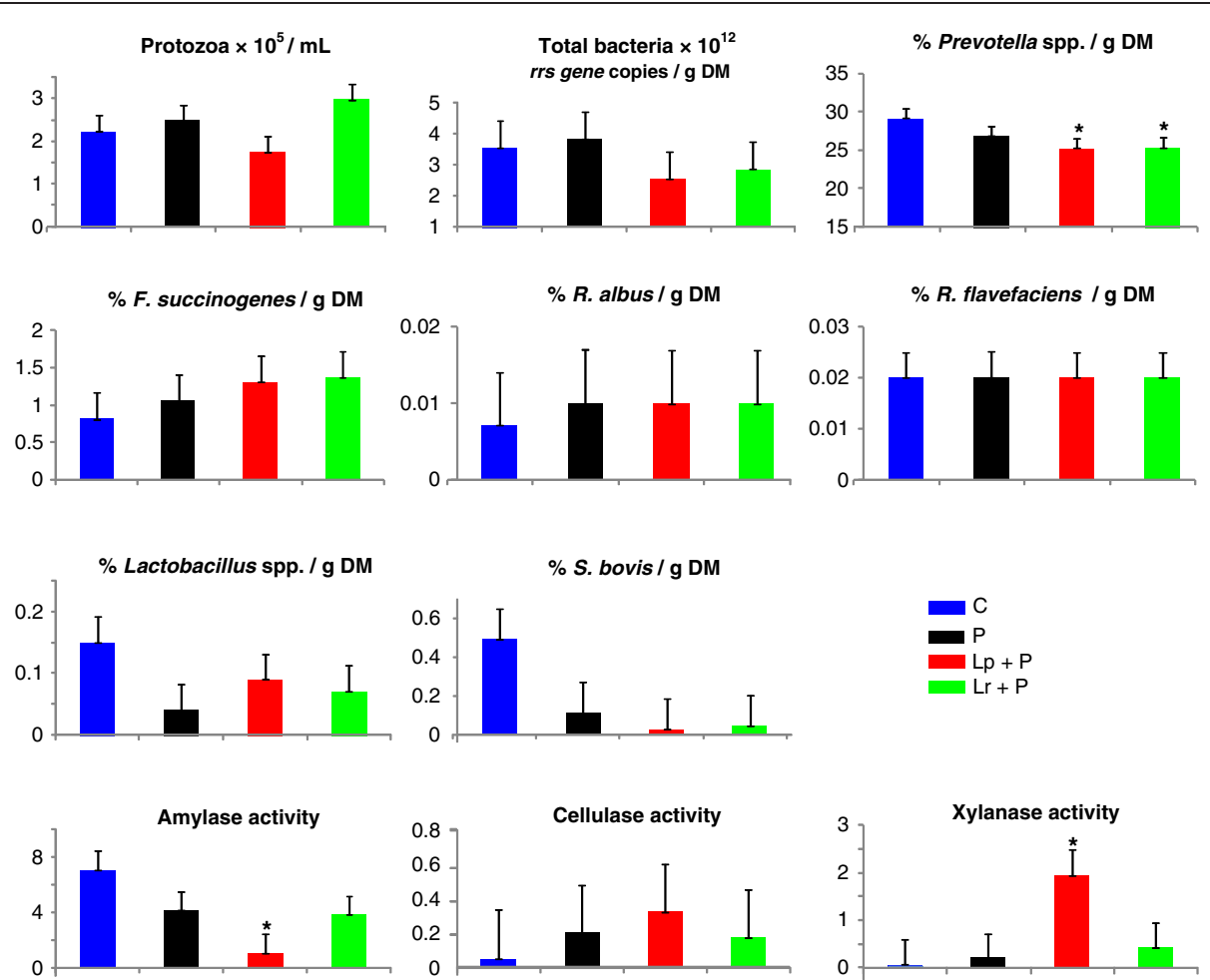

Figure 3 Effects of bacterial probiotic supplementation on the rumen microbial parameters during corn-induced butyric subacute acidosis. Acidosis was induced during 3 consecutive days. Protozoa, bacteria and polysaccharidase activities were quantified $3 \mathrm{~h}$ after acidosis induction on day 3. Bacterial species are expressed as \% of total bacteria per gram of dry matter (DM). Polysaccharidase activities are expressed as $\mu \mathrm{mol}$ of reducing sugar/mg protein/h. The treatments were identified as $\mathrm{C}=$ control without probiotic; $\mathrm{P}=$ Propionibacterium P63; $L p+P=L$. plantarum $+P 63 ; L r+P=L$. rhamnosus $+P 63$. Each single point is a mean of 4 data points from the 4-period Latin square. Error bars represent standard error of the means. Probiotic treatments that significantly differ from control are indicated by * for $P \leq 0.05$.

$\mathrm{Lp}+\mathrm{P}$ and $\mathrm{Lr}+\mathrm{P}$ had a higher $\mathrm{pH}$ nadir compared with $\mathrm{C}$ (+ $0.46 \mathrm{pH}$ units; $P<0.05$ ), but only $\mathrm{Lp}+\mathrm{P}$ had higher mean ruminal $\mathrm{pH}(+0.25 \mathrm{pH}$ units, $P<0.05)$. The rise in $\mathrm{pH}$ was associated with a decrease in total VFA concentration $(-24 \%, P<0.05)$, and butyrate proportion $(P<0.05)$ and an increase in acetate and minor VFAs $(P<0.05)$. Feeding $\mathrm{P}$ also reduced total VFAs $(P<0.05)$, and numerically changed individual VFAs proportions as did $\mathrm{Lr}+\mathrm{P}$. However, neither probiotic significantly affected mean ruminal $\mathrm{pH}$.

Propionic SARA was characterized in $C$ wethers by a mean ruminal $\mathrm{pH}$ of 5.67 , total VFA concentration of $114 \mathrm{mM}, 22.5 \%$ of propionate and less than $3 \mathrm{mM}$ of lactate (Table 3). These findings are in agreement with earlier reported studies on propionic SARA induced by intraruminal dosing of beet pulp [13] and in normally fed cattle [44,45]. Probiotic supplementation did not affect significantly the microbial composition, polysaccharidase activities and fermentation patterns that remained similar among treatments (Figure 4). For amylase activity, this could be explained by the fact that beet pulp does not contain starch but sucrose, and that the development of amylase activity requires starch availability
[46]. Without clear effects on microbial and fermentation patterns, explanations are still lacking on how the probiotics increased mean $(+0.27 \mathrm{pH}$ units on average, for $\mathrm{P}$ and $\mathrm{Lr}+\mathrm{P})$ and minimum ruminal $\mathrm{pH}(0.29 \mathrm{pH}$ units on average, for $\mathrm{P}$ and $\mathrm{Lr}+\mathrm{P})$. In contrast to $\mathrm{qPCR}$, which showed subtle changes in the bacterial community, DGGE analysis revealed that bacterial structure was affected by probiotic supplementation, insofar as supplemented wethers clustered together with 83.2 and $86.4 \%$ similarity for butyric and propionic SARA, respectively (Figure 2 ). These complementary results indicate that shifts in the bacterial communities may result in unchanged fermentation patterns and that these shifts concerned bacterial groups that differ from those targeted by qPCR. Also, similarly to lactic acidosis, the richness index was greater at $\mathrm{d} 3$ than at d1, with an average of 26 vs. 18 and 27 vs. 22 bands for butyric and propionic SARA, respectively. This result conflicts with recent work reporting a decrease in bacterial richness when SARA was induced in dairy cows [2]. This discordance could be due to the mode of acidosis induction (intraruminal dosing $v s$. normal feeding) or the nature of the samples, as DNA extraction was achieved from ruminal liquid in the reported study, whereas we used 

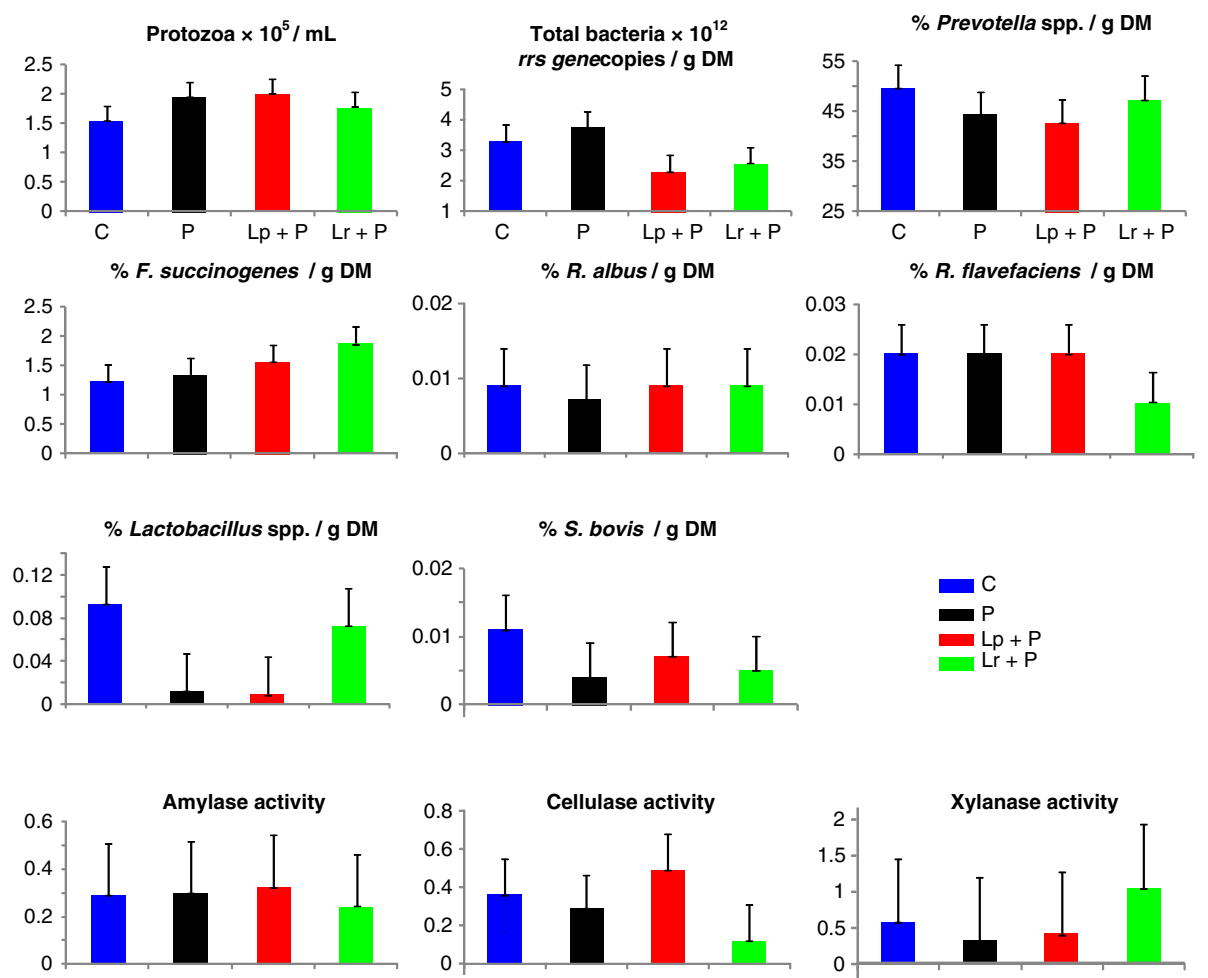

Figure 4 Effects of bacterial probiotic supplementation on the rumen microbial parameters during beet pulp-induced propionic subacute acidosis. Acidosis was induced during 3 consecutive days. Protozoa, bacteria and polysaccharidase activities were quantified $3 \mathrm{~h}$ after acidosis induction on day 3. Bacterial species are expressed as \% of total bacteria per gram of dry matter (DM). Polysaccharidase activities are expressed as $\mu \mathrm{mol}$ of reducing sugar/mg protein/h. The treatments were identified as $\mathrm{C}=$ control without probiotic; $\mathrm{P}=$ Propionibacterium P63; $L p+P=L$. plantarum $+P 63 ; L r+P=L$. rhamnosus $+P 63$. Each single point is a mean of 4 data points from the 4-period Latin square. Error bars represent standard error of the means. Probiotic treatments that significantly differ from control are indicated by * for $P \leq 0.05$.

whole ruminal content (liquid + solid). Also, wethers supplemented with probiotics exhibited a higher richness index than controls, with 31 vs. 21 and 31 vs. 23 bands on average for butyric and propionic SARA, respectively. For butyric SARA, an intense band was observed with Lp + P. Sequencing and identification of the band can establish a causal link between a species and changes observed in $\mathrm{pH}$ and xylanase activity. As for lactic acidosis, further sequencing experiments are required to enhance our knowledge of how SARA and probiotics affect the rumen bacterial structure and activity.

Among the few studies published on the use of bacterial probiotics, only two $[47,48]$ tested the effects of Lactobacillus and Propionibacterium strains on ruminal fermentation during SARA. One of the studies tested P. acidipropionici $\mathrm{P} 15$ alone $\left(\mathrm{P} 15 ; 1 \times 10^{9} \mathrm{CFU} / \mathrm{d}\right)$ or in combination with E. faecium 212 (PE; $1 \times 10^{9}+$ $\left.1 \times 10^{9} \mathrm{CFU} / \mathrm{d}\right)$ on steers fed a $90 \%$ steam-rolled barley based diet. The probiotics did not affect ruminal $\mathrm{pH}$, but P15 supplementation increased butyrate proportion and protozoa population with a concomitant reduction in amylolytic bacteria and S. bovis counts [47]. In the other study, P. freudenreichii PF24 in association with
Lb. acidophilus $747\left(1 \times 10^{9}+2 \times 10^{9}\right.$ CFU/d $)$ or Lb. acidophilus 747 and Lb. acidophilus $45\left(1 \times 10^{9}+2 \times 10^{9}+\right.$ $\left.5 \times 10^{8} \mathrm{CFU} / \mathrm{d}\right)$ given to mid-lactation Holstein dairy cows fed a $41 \%$ concentrate based diet did not affect the ruminal fermentations or $\mathrm{pH}$, which was approximately 6.15 for control and probiotic-supplemented cows [48]. According to our present hypothesis that probiotics become effective when the ruminal ecosystem is unstable, it appears that the conditions were not acidotic enough in the study of Raeth-Knight et al. [48], whereas the effects reported by Ghorbani et al. [47] may indicate a decrease in acidosis risk even though the ruminal $\mathrm{pH}$ was not affected by probiotic supplementation [47]. In other studies reporting the use of probiotic bacteria, beneficial effects on ruminal $\mathrm{pH}$ were only observed for treatments associating bacteria and yeast $[11,12]$, and never for bacteria alone [29,47-50]. Thus the beneficial effects on $\mathrm{pH}$ reported by Nocek et al. [11] and Chiquette [12] were probably not specific to the bacteria used, and may be attributed to $S$. cerevisiae, which has been shown to stabilize ruminal $\mathrm{pH}[8,9,51]$. However, a synergistic effect cannot be excluded as, to our knowledge, there have been no studies comparing yeast and bacteria 
used alone and in association. The present work is the first to report a specific positive effect of bacterial probiotics on ruminal $\mathrm{pH}$ during SARA. The mode of action of these probiotics, consisting of Lactobacillus and Propionibacterium selected strains, could not be clearly associated with quantitative characteristics of the rumen microbial ecosystem such as bacterial and protozoal populations.

\section{Conclusion}

This study shows for the first time that Lactobacillus and Propionibacterium probiotic strains may be effective in stabilizing ruminal $\mathrm{pH}$ and therefore preventing SARA risk, but they were not effective against lactic acidosis. The present results also suggest that the effectiveness of probiotics is compromised by ruminal fermentations, and are effective when the ruminal ecosystem is unstable. Although their mode of action needs to be further elucidated, we hypothesize that the effect of the probiotic strains used on ruminal $\mathrm{pH}$ was achieved by modulating the rumen microbiota, which was more diverse, by improving cellulolytic activity and by limiting the proliferation of lactic acidproducing bacteria. The combination of lactobacilli and Propionibacterium P63 seems to be more efficient in preventing SARA than P63 alone, possibly due to a synergistic effect between the strains.

\section{Abbreviations}

BW: Body weight; CFU: Colony forming unit; DGGE: Denaturing gradient gel electrophoresis; DM: Dry matter; Lp + P: Lactobacillus plantarum plus P63; Lr+P: Lactobacillus rhamnosus plus P63; P63: Propionibacterium strain P63; qPCR: Quantitative PCR; SARA: Subacute ruminal acidosis; VFA: Volatile fatty acids.

\section{Competing interest}

The probiotics used are the property of Danisco SAS.

\section{Author's contributions}

$A L, P N, C M, M S, D P M$ and $C B$ designed the study. CB initiated the funding from DanisCo. AL, PN, CM, MS and DPM participated in the animal experiment. AL did the biochemical and molecular experiments, analyzed the data and drafted the manuscript. AL, PN, CM, DPM and CB revised the manuscript. All authors read and approved the final manuscript.

\section{Acknowledgement}

A. Lettat was the recipient of a CIFRE Danisco SAS research fellowship. The authors thank the skilled INRA personnel of the Herbivores Research Unit, especially D. Durand for performing animal surgery, S. Alcouffe, M. Fabre and D. Roux, for the care of animals, L. Genestoux and V. Chomilier for their aid in performing laboratory analysis. We also thank E.A. Galbraith and A.H. Smith (Danisco, Waukesha, WI) and B. Meunier (INRA Clermont Ferrand/Theix) for their help in DGGE analysis, as well as P. Mosoni (UR 454 Microbiologie, INRA Clermont Ferrand/Theix) and P. Horvath (Danisco, SAS France) for providing the $16 \mathrm{~S}$ rDNA standards.

\section{Author details}

'INRA, UR1213 Herbivores, Centre de Recherches de Clermont-Ferrand/Theix, F-63122 Saint Genès, Champanelle, France. ${ }^{2}$ Danisco France SAS, Zone d'Activités de Buxières, BP 10, F-86220, Dangé-Saint-Romain, France. ${ }^{3}$ Danisco France SAS, 20 rue Brunel, F-75017, Paris, France. ${ }^{4}$ Present address: Dairy and Swine R\&D Centre, Sherbrooke, QC, Canada.

Received: 20 February 2012 Accepted: 21 June 2012 Published: 19 July 2012

\section{References}

1. Krause DO, Denman SE, Mackie Rl, Morrison M, Rae AL, Attwood GT, McSweeney CS: Opportunities to improve fiber degradation in the rumen: microbiology, ecology, and genomics. FEMS Microbiol Rev 2003, 27(5):663-693.

2. Khafipour E, Li S, Plaizier JC, Krause DO: Rumen microbiome composition determined using two nutritional models of subacute ruminal acidosis. Appl Environ Microbiol 2009, 75(22):7115-7124.

3. Enemark JMD: The monitoring, prevention and treatment of sub-acute ruminal acidosis (SARA): A review. Vet J 2008, 176(1):32-43.

4. Martin C, Brossard L, Doreau M: Mécanismes d'apparition de l'acidose ruminale latente et conséquences physiopathologiques et zootechniques. INRA Prod Anim 2006, 19:93-108.

5. Kleen JL, Hooijer GA, Rehage J, Noordhuizen JPTM: Subacute ruminal acidosis (SARA): A review. J Vet Med A 2003, 50(8):406-414.

6. Meschy F, Bravo D, Sauvant D: Analyse quantitative des réponses des vaches laitières à l'apport de substances tampon. INRA Prod Anim 2004, 17:11-18.

7. Packer EL, Clayton EH, Cusack PMV: Rumen fermentation and liveweight gain in beef cattle treated with monensin and grazing lush forage. Aust Vet J 2011, 89(9):338-345.

8. Chaucheyras-Durand F, Walker ND, Bach A: Effects of active dry yeasts on the rumen microbial ecosystem: Past, present and future. Anim Feed Sci Technol 2008, 145(1-4):5-26.

9. Desnoyers M, Giger-Reverdin S, Bertin G, Duvaux-Ponter C, Sauvant D: Meta-analysis of the influence of Saccharomyces cerevisiae supplementation on ruminal parameters and milk production of ruminants. J Dairy Sci 2009, 92(4):1620-1632.

10. Meissner HH, Henning PH, Horn CH, Leeuw K-J, Hagg FM, Fouché G: Ruminal acidosis: a review with detailed reference to the controlling agent Megasphaera elsdenii NCIMB 41125. S Afr J Anim Sci 2010, 40(2):79-100.

11. Nocek JE, Kautz WP, Leedle JAZ, Block E: Direct-fed microbial supplementation on the performance of dairy cattle during the transition period. J Dairy Sci 2003, 86(1):331-335.

12. Chiquette $\mathrm{J}$ : Evaluation of the protective effect of probiotics fed to dairy cows during a subacute ruminal acidosis challenge. Anim Feed Sci Technol 2009, 153(3-4):278-291.

13. Lettat $A$, Noziere $P$, Silberberg $M$, Morgavi DP, Berger C, Martin C: Experimental feed induction of ruminal lactic, propionic, or butyric acidosis in sheep. J Anim Sci 2010, 88(9):3041-3046.

14. Edwards JE, Huws SA, Kim EJ, Kingston-Smith AH: Characterization of the dynamics of initial bacterial colonization of nonconserved forage in the bovine rumen. FEMS Microbiol Ecol 2007, 62(3):323-335.

15. Stevenson DM, Weimer PJ: Dominance of Prevotella and low abundance of classical ruminal bacterial species in the bovine rumen revealed by relative quantification real-time PCR. App/Microbio/Biotechnol 2007, 75(1):165-174.

16. Furet J-P, Firmesse O, Gourmelon M, Bridonneau C, Tap J, Mondot S, Doré J, Corthier G: Comparative assessment of human and farm animal faecal microbiota using real-time quantitative PCR. FEMS Microbiol Ecol 2009, 68(3):351-362.

17. Jones $\mathrm{S}$, Lennon J: Evidence for limited microbial transfer of methane in a planktonic food web. AquatMicrobEcol 2009, 58(1):45-53.

18. Kim YG, Lee TH, Park TJ, Park HS, Lee SH: Identification of dominant microbial community in aerophilic biofilm reactors by fluorescence in situ hybridization and PCR-denaturing gradient gel electrophoresis. Korean J Chem Eng 2009, 26(3):685-690.

19. Walter J, Tannock GW, Tilsala-Timisjarvi A, Rodtong S, Loach DM, Munro K, Alatossava T: Detection and identification of gastrointestinal Lactobacillus species by using denaturing gradient gel electrophoresis and species-specific PCR primers. Appl Environ Microbiol 2000, 66(1):297-303.

20. Smith $A H$, Mackie Rl: Effect of condensed tannins on bacterial diversity and metabolic activity in the rat gastrointestinal tract. Appl Environ Microbiol 2004, 70(2):1104-1115.

21. Fromin N, Hamelin J, Tarnawski S, Roesti D, Jourdain-Miserez K, Forestier N, Teyssier-Cuvelle S, Gillet F, Aragno M, Rossi P: Statistical analysis of denaturing gel electrophoresis (DGE) fingerprinting patterns. Environ Microbiol 2002, 4(11):634-643.

22. Jouany J-P, Senaud J: Influence des ciliés du rumen sur l'utilisation digestive de différents régimes riches en glucides solubles et sur les 
produits terminaux formés dans le rumen. II. — Régimes contenant de I'inuline, du saccharose et du lactose. ReprodNutrDévelop 1983, 23(3):607-623

23. Martin C, Michalet-Doreau B: Variations in mass and enzyme activity of rumen microorganisms: Effect of barley and buffer supplements. J Sci Food Agric 1995, 67(3):407-413.

24. Lever M: Carbohydrate determination with 4-hydroxybenzoic acid hydrazide (PAHBAH): Effect of bismuth on the reaction. Anal Biochem 1977, 81(1):21-27.

25. Pierce J, Suelter $\mathrm{CH}$ : An evaluation of the Coomassie brilliant blue G-250 dye-binding method for quantitative protein determination. Anal Biochem 1977, 81(2):478-480.

26. Park G, Oh H, Ahn S: Improvement of the ammonia analysis by the phenate method in water and wastewater. Bull Korean Chem Soc 2009, 30:2032-2038

27. Owens FN, Secrist DS, Hill WJ, Gill DR: Acidosis in cattle: a review. J Anim Sci 1998, 76(1):275-286.

28. Khafipour E, Krause DO, Plaizier JC: A grain-based subacute ruminal acidosis challenge causes translocation of lipopolysaccharide and triggers inflammation. J Dairy Sci 2009, 92(3):1060-1070

29. Beauchemin KA, Yang WZ, Morgavi DP, Ghorbani GR, Kautz W, Leedle JA: Effects of bacterial direct-fed microbials and yeast on site and extent of digestion, blood chemistry, and subclinical ruminal acidosis in feedlot cattle. J Anim Sci 2003, 81(6):1628-1640.

30. Sauvant D, Meschy F, Mertens D: Components of ruminal acidosis and acidogenic effects of diets. INRA Prod Anim 1999, 12:49-60.

31. McLaughlin CL, Thompson A, Greenwood K, Sherington J, Bruce C: Effect of acarbose on acute acidosis. J Dairy Sci 2009, 92(6):2758-2766.

32. Counotte GHM, Prins RA, Janssen RHAM, deBie MJA: Role of Megasphaera elsdenii in the fermentation of DL-[2-13 C]lactate in the rumen of dairy cattle. Appl Environ Microbiol 1981, 42(4):649-655.

33. Calsamiglia S, Busquet M, Cardozo PW, Castillejos L, Ferret A: Invited review: Essential oils as modifiers of rumen microbial fermentation. J Dairy SCi 2003, 90:2580-2595.

34. Allison MJ, Dougherty RW, Bucklin JA, Snyder EE: Ethanol accumulation in the rumen after overfeeding with readily fermentable carbohydrate. Science 1964, 144(3614):54-55.

35. Nagaraja TG, Bartley EE, Fina LR, Anthony HD: Relationship of rumen gramnegative bacteria and free endotoxin to lactic acidosis in cattle. J Anim Sci 1978, 47(6):1329-1337.

36. Tailliez P: Les lactobacilles: propriétés, habitats, rôle physiologique et intérêt en santé humaine. Antibiotiques 2004, 6(1):35-41.

37. Shu Q, Gill HS, Leng RA, Rowe JB: Immunization with a Streptococcus bovis vaccine administered by different routes against lactic acidosis in sheep. Vet J 2000, 159(3):262-269.

38. Hungate RE (1968) Ruminal fermentation. In: Code CF (ed) Handbook of Physiology. Alimentary canal. Bile, digestion, ruminant physiology. American Physiological Society, Washington DC, pp 2725-2745

39. Russell JB, Hino T: Regulation of lactate production in Streptococcus bovis: A spiraling effect that contributes to rumen acidosis. J Dairy Sci 1985, 68(7):1712-1721.

40. Brossard L, Martin C, Chaucheyras-Durand F, Michalet-Doreau B: Protozoa involved in butyric rather than lactic fermentative pattern during latent acidosis in sheep. ReprodNutrDev 2004, 44(3):195-206.

41. Silberberg M, Chaucheyras-Durand F, Commun L, Richard-Mialon MM, Martin C, Morgavi DP: Repeated ruminal acidotic challenges in sheep: effects on $\mathrm{pH}$ and microbial ecosystem and influence of Active Dry Yeasts. J Dairy Sci 2009, 92:1. E-Suppl.

42. Lal SB, Dwivedi SK, Sharma MC, Swarup D: Biopathological studies in experimentally induced ruminal acidosis in goat. Indian J Anim Sci 1992, 62:200-204

43. Doreau M, Ollier A, Michalet-Doreau B: An atypical ase of ruminal fermentations leading to ketosis in early lactating cows. Rev Med Vet 2001, 152:301-306

44. Gozho GN, Krause DO, Plaizier JC: Ruminal lipopolysaccharide concentration and inflammatory response during grain-induced subacute ruminal acidosis in dairy cows. J Dairy Sci 2007, 90(2):856-866

45. Khafipour E, Krause DO, Plaizier JC: Alfalfa pellet-induced subacute ruminal acidosis in dairy cows increases bacterial endotoxin in the rumen without causing inflammation. J Dairy Sci 2009, 92(4):1712-1724

46. Nozière P, Michalet-Doreau B: Effects of amount and availability of starch on amylolytic activity of ruminal solid-associated microorganisms. J Sci Food Agric 1997, 73(4):471-476.

47. Ghorbani GR, Morgavi DP, Beauchemin KA, Leedle JA: Effects of bacterial direct-fed microbials on ruminal fermentation, blood variables, and the microbial populations of feedlot cattle. J Anim Sci 2002, 80(7):1977-1985.

48. Raeth-Knight ML, Linn JG, Jung HG: Effect of direct-fed microbials on performance, diet digestibility, and rumen characteristics of Holstein dairy cows. J Dairy Sci 2007, 90(4):1802-1809.

49. Stein DR, Allen DT, Perry EB, Bruner JC, Gates KW, Rehberger TG, Mertz K, Jones $D$, Spicer $L$ : Effects of feeding propionibacteria to dairy cows on milk yield, milk components, and reproduction. J Dairy Sci 2006, 89(1):111-125.

50. Chiquette J, Allison MJ, Rasmussen MA: Prevotella bryantii 25A used as a probiotic in early-lactation dairy cows: effect on ruminal fermentation characteristics, milk production, and milk composition. J Dairy Sci 2008, 91(9):3536-3543.

51. Chaucheyras-Durand F, Durand H: Probiotics in animal nutrition and health. Beneficial Microbes 2010, 1(1):3-9.

doi:10.1186/1471-2180-12-142

Cite this article as: Lettat et al:: Rumen microbial and fermentation characteristics are affected differently by bacterial probiotic supplementation during induced lactic and subacute acidosis in sheep. BMC Microbiology 2012 12:142.

\section{Submit your next manuscript to BioMed Central and take full advantage of:}

- Convenient online submission

- Thorough peer review

- No space constraints or color figure charges

- Immediate publication on acceptance

- Inclusion in PubMed, CAS, Scopus and Google Scholar

- Research which is freely available for redistribution 